\title{
Correlation and Regression Analyses for Cane and Sugar Yields Across Their Components under Bud Chips and Conventional Planting Methods in SugarCane.
}

\author{
Abo-Elwafa A. ${ }^{1}$, M. O. A. Galal ${ }^{2}$, H.M.M. Nosier ${ }^{3}$, A.N. El- \\ Soghier- Mohamed ${ }^{3}$
}

${ }^{1}$ Agronomy Department, Faculty of Agriculture, Assiut University, Egypt

${ }^{2}$ Sugar Crops Research Institute, ARC, Giza

${ }^{3}$ Egyptian Sugar and Integrated Industries Company

Corresponding author: atif59eg@yahoo.com or atif@aun.edu.eg

\section{Abstract}

The present study was carried out in a privet farm in El-Shaghap Region, South Esna of Luxor Governorate, Egypt (latitude of $25.30^{\circ} \mathrm{N}$ and longitude of $32.30^{\circ} \mathrm{E}$ ). The work was conducted during the two plant-crop seasons of 2017/2018 and 2018/2019 to study the sugarcane planting using bud chips and conventional methods. Four sugarcane varieties G.T.54-9, G.84-47, G.2003-47 and C.57-14 were tested in this study. The experimental design was a split plot design with four replications. The four varieties were randomly distributed to the main plots and the two planting methods (conventional method and bud chips) assigned as sub-plot (42 m2). Each plot contains six rows with the length of seven meters/row and one meter of row width.

The results indicated that unique and high positive estimates of correlation coefficients were recorded between seeding survival $\%$ and each of millable cane length, millable cane weight, cane yield/ fed, brix, sucrose content, purity \%, sugar recovery $\%$, pol and sugar yield/fed across bud chips planting method. Otherwise, the previous results were not found for conventional planting method, reflecting the remarkable effect of bud chips planting method on correlation coefficients corresponding to the seeding survival produced using that method. Brix recorded high and positive correlation with each of sucrose $\%$, purity $\%$, sugar recovery $\%$, pol $\%$ and sugar yield/ fed across both planting methods.

It is remarkable results that the correlation coefficients between each of sucrose $\%$, purity $\%$, sugar recovery $\%$ and pol $\%$ were equal or close to unity, reflecting the very strong genetic make-up of those traits. 
Regression analysis revealed that the predictors traits, i.e., sugar yield/fed., millable cane diameter, millable cane length, seedling survival\%, millable cane weight and number of millable cane/fed. could be used as powerful selection criteria for high cane yield/fed. Moreover, the predictors traits, i.e., cane yield/fed, stalk length elongation, millable cane length, millable cane diameter, number of millable cane/fed, stalk survival\%, pol\%, brix $\%$ and sucrose $\%$ could be used as powerful selection criteria for high sugar yield/fed.

\section{Key Words: Correlation coefficient, Regression analysis, Sugarcane transplanting, bud chips.}

\section{Introduction}

Sugarcane (Saccharum officinarum L) is grown commercially using stalk cuttings or setts, and this method of cultivation has gradually become uneconomical because the cost of "seed cane" used for replanting which represents more than $20 \%$ of the total production cost. In the conventional system prevailing in Egypt, about $6-7$ tons of seed cane/ fed. (about 3.5\% of the total production) is used as planting material, which consists of about $25-30 \mathrm{~cm}$ of stem cuttings with $2-3$ buds. This large mass of planting material poses a major problem in the transportation, handling and storage of the cane seed and is subjected to rapid degradation, which reduces the viability of the sprouts.

An alternative method to reduce the mass and improve the quality of seed cane would be to plant excised axillary buds of cane stalk, popularly known as bud chips. These bud chips are less bulky, easily transportable and more economical seed material. The bud chip technology holds great promise in rapid multiplication of new cane varieties. If bud chips are used 150-200 $\mathrm{Kg} / \mathrm{fed}$ of material is sufficient for planting which results in saving of about $97 \%$ of cane by weight. This is most economical in the cost of cultivation of the crop and incidentally saves a few thousand tons of raw material that can be used for extracting sugar rather than been buried in the soil as seed.

Studies have shown that bud chip could be one of the most viable and economical planting material in reducing the cost of sugarcane production (Radha et al. 2010). Significantly higher 
yield was produced by transplanted cane of 144.5 t/ha and followed by soil bed settings of $119.2 \mathrm{t} / \mathrm{ha}$ (Hossain, 1989). Sundara (1995) found that transplanted cane gave 22.4 and $24.6 \%$ higher cane and sugar yields, respectively comparing to the set planted crop.

Galal (2015) reported that planting sugarcane using seedlings from bud chips saved about $97 \%$ from the weight of stalk material and statistically higher than conventional method on sprouting and germination percentage. The bud chip is a viable and economical planting technique for reducing total sugarcane production costs. Also, Galal et al. (2015) reported that transplanting of sugarcane seedlings in April could be used without any reduction in cane yield and allowing the harvesting of a winter crop such as broad bean.

A significant and positive correlation coefficients were found between sugar yield and each of cane yield, number of millable cane, stalk height, sucrose $\%$, purity $\%$ and sugar recovery $\%$. Linear regression analysis showed that cane yield/fed, number of millable cane, stalk height, sucrose $\%$, purity $\%$ and sugar recovery $\%$ were the most effective traits affecting sugar yield (Ahmed et al. 2007).

A positive and highly significant correlation between cane yield and its components viz., single stalk weight, stalk length and millable cane number was reported (Panhwar et al. 2003; Thippeswamy et al., 2003; Chaudhary \& Joshi 2005; Kadian et al. 2006; Tyagi \& Lal 2007; Devendra \& Sanjay 2014; Kumar \& Kumar 2014; Tena et al. 2016; Pandya \& Patel, 2017).

Positive association of cane yield with cane diameter, plant height, number of millable canes, single cane weight, commercial cane sugar (CCS\%) at harvest, pol \%, number of shoots per ha and purity (Agrawal \& Kumar 2018; Ahmed et al., 2019). Abo-Elwafa (2011) found significant and high positive correlation coefficients between weight and number of stalk / plot in plant crop, first and second ratoons. Abo-Elwafa et al., (2015) evaluated some somaclones of sugarcane regenerated from the GT-54 9 variety and found high and positive correlations between sugar yield and each of sugar $\%$ in gram, sweetness $\%$ and brix. Also, brix, sugar \%, 
purity $\%$ and sugar yield were correlated with each other in high and positive estimates. Swamy Gowda et al., (2016) reported that the cane yield was positively and significantly correlated with sugar yield, single stalk weight, number of tillers and stalk length. There was also positive significant correlation of number of millable cane and stalk diameter with cane yield. Cane yield was negatively and significantly correlated with brix and pol, whereas, sugar yield showed positive and significant correlation with single stalk weight, cane length, CCS, pol and purity. Anbanandan et al., (2020) determined the relationship between sugar yield and its components. Commercial cane sugar and brix exerted maximum positive direct effect on sugar yield/plot. Therefore, selection and manipulation of any one of these traits is likely to improve sugar yield per plot.

Stepwise regression analysis indicated that the cane yield and brix value yielded highest R2 value of 0.699 with sugar recovery (Nosheen \& Ashraf, 2003) and sweetness and purity presented in an unique model with R2 equal to unity $(=1)$ and were superior to determine and selection for sugar yield in sugarcane (Abo-Elwafa et al., 2015). Moreover, sugar yield was largely depended on both cane yield and sucrose percent (Thippeswamy et al., 2003). Also, the CCS\% and brix exerted the maximum positive direct effect on sugar yield/plot. Brix also had indirect effect on sugar yield through sucrose percent, commercial cane sugar percent and cane yield/ plot (Anbanandan et al., (2020).

The current investigation was taken up to study the correlation among different characters as well as multiple regression analysis for cane yield or sugar yield as a dependent trait across all other independent traits through bud chips and conventional planting methods in two seasons and over both planting methods and seasons to understand the inter relationship among the characters.

\section{Materials and Methods}

The present study was carried out in a privet farm in ElShaghap Region, South Esna of Luxor Governorate, Egypt (latitude of $25.25^{\circ} \mathrm{N}$ and longitude of $32.31^{\circ} \mathrm{E}$ ). Soil type of the 
experimental location was sandy loam with an average $\mathrm{pH}$ of 8.1, available $\mathrm{N}$ of $20 \mathrm{ppm}$, Available $\mathrm{P}$ of $11 \mathrm{ppm}$, and available $\mathrm{K}$ of $516 \mathrm{ppm}$. The work was conducted during the two plant-crop seasons of 2017/2018 and 2018/2019. Four sugarcane varieties, i.e., G.T.54-9, G.84-47, G.2003-47 and C.57-14 were tested in this study.

The tested planting methods include conventional method (direct set planting) and planting using bud chips. Direct set planting was carried out using three budded cane sets planted directly in the main field on May1st using a total of 21 sets/row and 126 sets/plot (=12600 sets/ fed). Also, seedling transplanting was planted using 18 seedlings/row (=108 seedlings/plot) $(=10800$ seedlings/fed), which transplanted in the main field on May1st in the two seasons. Seedling distance was maintained at approximately $35 \mathrm{~cm}$. Seedling transplants were prepared as described herein:

\section{Nursery preparation:}

Nursery preparation started on March1st. Selected fresh harvested stalks free from disease and pests were topped leaves and removed and bud chips were excised manually using Bud Chipping Machine. Single budded chips from the healthy cane stalks were used. Bud chips were soaked for five minutes in the Rizolex-T 50\% fungicide. The buds were sown in an upright position at $3-5 \mathrm{~cm}$ depth in polythene bags of $15 \times 8 \mathrm{~cm}$ dimension filled with soil taken from the permanent field. The nursery was irrigated daily and fertilized as indicated below.

A fixed dose of phosphorus fertilizer was applied during land preparation at a rate of $60 \mathrm{~kg} \mathrm{P} 2 \mathrm{O} 5 / \mathrm{fed}$ as calcium super phosphate $(15.5 \% \mathrm{P} 2 \mathrm{O} 5)$ to the permanent field before collecting the needed soil that was used to fill the bags. Potassium fertilizer was added at $48 \mathrm{~kg} \mathrm{~K} 2 \mathrm{O} / \mathrm{fed}$ as potassium sulphate (48\% $\mathrm{K} 2 \mathrm{O}$ ) once, with the second N-dose.

The nitrogen fertilizer as urea $(46 \% \mathrm{~N})$ was applied at rate of $240 \mathrm{~kg}$ nitrogen/ fed, which was split into three doses (at the nursery, after the 1st and 2nd hoeing, i.e., 45 and 75 days from planting) were added to the permanent field except for the first dose at bud chips that was added in the nursery. 
Data of temperature records of both growing season are given in Table (1) from the data of the Egyptian metrological authority.

The experimental design was a split plot design with four replications. The four varieties were randomly distributed to the main plots and the two planting methods (conventional method and bud chips) assigned as sub-plot (42 $\mathrm{m} 2$ ). Each plot contains six rows with the length of seven meters/row and one meter of row width.

Table1: Average monthly-recorded temperature measurements during the two experimental seasons.

\begin{tabular}{|c|c|c|c|c|c|c|}
\hline \multirow{2}{*}{ Month } & \multicolumn{3}{|c|}{$2017-2018$} & \multicolumn{3}{c|}{$2018-2019$} \\
\cline { 2 - 7 } & \multicolumn{3}{|c|}{ Temp. $\left({ }^{\circ}\right.$ C) } & \multicolumn{3}{c|}{ Temp. $\left({ }^{\circ}\right.$ C) } \\
\cline { 2 - 7 } & Max. & Min. & Avg. & Max. & Min. & Avg. \\
\hline March & $\mathbf{2 8 . 3 5}$ & $\mathbf{1 2 . 3 2}$ & $\mathbf{2 0 . 3 4}$ & $\mathbf{3 3 . 7 9}$ & $\mathbf{1 5 . 7 6}$ & $\mathbf{2 4 . 7 8}$ \\
\hline April & $\mathbf{3 4 . 6 3}$ & $\mathbf{1 8 . 3 8}$ & $\mathbf{2 6 . 5 0}$ & $\mathbf{3 5 . 1 6}$ & $\mathbf{1 9 . 0 6}$ & $\mathbf{2 7 . 1 1}$ \\
\hline May & $\mathbf{3 9 . 2 5}$ & $\mathbf{2 2 . 2 8}$ & $\mathbf{3 0 . 7 7}$ & $\mathbf{3 9 . 8 2}$ & $\mathbf{2 5 . 0 9}$ & $\mathbf{3 2 . 4 6}$ \\
\hline June & $\mathbf{4 1 . 6 1}$ & $\mathbf{2 5 . 7 4}$ & $\mathbf{3 3 . 6 8}$ & $\mathbf{4 1 . 1 8}$ & $\mathbf{2 6 . 2 9}$ & $\mathbf{3 3 . 7 3}$ \\
\hline July & $\mathbf{4 0 . 8 9}$ & $\mathbf{2 4 . 3 6}$ & $\mathbf{3 2 . 6 2}$ & $\mathbf{4 0 . 4 0}$ & $\mathbf{2 6 . 3 9}$ & $\mathbf{3 3 . 3 9}$ \\
\hline August & $\mathbf{4 1 . 6 5}$ & $\mathbf{2 6 . 6 0}$ & $\mathbf{3 4 . 1 2}$ & $\mathbf{4 0 . 8 1}$ & $\mathbf{2 6 . 5 5}$ & $\mathbf{3 3 . 6 8}$ \\
\hline September & $\mathbf{4 2 . 3 3}$ & $\mathbf{2 7 . 2 9}$ & $\mathbf{3 4 . 8 1}$ & $\mathbf{3 9 . 3 9}$ & $\mathbf{2 5 . 1 0}$ & $\mathbf{3 2 . 2 5}$ \\
\hline October & $\mathbf{4 0 . 8 4}$ & $\mathbf{2 6 . 1 5}$ & $\mathbf{3 3 . 5 0}$ & $\mathbf{3 5 . 2 3}$ & $\mathbf{2 0 . 9 4}$ & $\mathbf{2 8 . 0 9}$ \\
\hline November & $\mathbf{3 6 . 7 3}$ & $\mathbf{2 1 . 5 1}$ & $\mathbf{2 9 . 1 2}$ & $\mathbf{2 8 . 1 3}$ & $\mathbf{1 3 . 8 5}$ & $\mathbf{2 0 . 9 9}$ \\
\hline December & $\mathbf{3 0 . 5 9}$ & $\mathbf{1 5 . 1 4}$ & $\mathbf{2 2 . 8 7}$ & $\mathbf{2 2 . 4 1}$ & $\mathbf{9 . 0 9}$ & $\mathbf{1 5 . 7 5}$ \\
\hline January & $\mathbf{2 6 . 6 5}$ & $\mathbf{1 1 . 8 1}$ & $\mathbf{1 9 . 2 3}$ & $\mathbf{2 0 . 8 1}$ & $\mathbf{6 . 3 4}$ & $\mathbf{1 3 . 5 8}$ \\
\hline February & $\mathbf{2 8 . 0 7}$ & $\mathbf{1 1 . 1 1}$ & $\mathbf{1 9 . 5 9}$ & $\mathbf{2 3 . 3 9}$ & $\mathbf{9 . 9 6}$ & $\mathbf{1 6 . 6 8}$ \\
\hline
\end{tabular}

Cite after central laboratory for Agricultural clement ARC Egypt.

\section{Growth characters:}

\section{A. Early growth stage:}

- Seedling survival\% of bud chips (bud germination \%) and conventional planting after 45 days after planting in main field as follow:

Survival or germination $\%=[$ Total survival seedling or merged bud / Total number of sown seedlings or buds] x 100

- Number of tillers $/ \mathrm{m}^{2}$ : it was estimated at 8 sampling dates after 8 , $10,12,14,16,18,20$ and 22 weeks from planting in the permanent field. 
- Stalk length $(\mathrm{cm})$ : it was measured from soil surface to the top visible dewlap at 9 sampling dates every month, from 14 weeks to harvest.

\section{B. At harvest:}

At harvest ( $1{ }^{\text {st }}$ of April in both seasons), four guarded rows of each plot were harvested, topped and cleaned to estimate the following traits, which were calculated as a mean of the values measured from a stalk sample taken from one-meter portion of plot:

- Number of millable cane/fed.: it was count on one square meter base then converted into number per feddan.

- Millable cane length $(\mathrm{cm})$ : it was measured from soil surface to the top visible dewlap.

- Millable cane diameter $(\mathrm{cm})$ : it was measured at the middle part of stalk.

- Millable cane weight $(\mathrm{kg})$ : it was determined by determining the cane weight of the one-meter sample then dividing it by the number of millable cane.

\section{Juice quality characteristics:}

A representative sample of 20 millable canes from each plot was randomly taken at, stripped, cleaned and squeezed. The primary juice was extracted by electric pilot mill screened and mixed thoroughly on liter juice was taken in glass cylinder for measuring the juice characters.

- Total soluble solids (TSS \%) in cane juice (Brix percentage) was determined in the laboratory using brix hydrometer standardized at $20^{\circ} \mathrm{c}$.

- Sucrose percentage was determined using Sacharemeter according to A.O.A.C. (1995).

- Juice purity percentage was calculated according to the following formula:

$$
\text { Juice purity percentage }=\frac{\text { Sucrose percentage }}{\text { brix percentage }} \times 100
$$

- Sugar recovery percentage: it was calculated as follow:

Sugar recovery \% $=[$ sucrose $\%-0.4($ brix $\%$ - sucrose $\%) \times 0.73]$. 
Where: 0.4 and 0.73 are constants (Yadav \& Sharma, 1980).

- Pol percentage was calculated according to the following formula (Satisha et. al., 1996):

Pol percentage $=[$ brix $\%-0.4($ brix $\%-$ sucrose $\%) \times 0.73]$.

\section{III- Cane and sugar yields:}

- Cane yield (tons/fed): it was determined from the weight of the four middle guarded rows of each plot converted into value per fed.

- Sugar yield (tons/fed.): it was estimated according to the following equation:

Sugar yield (tons/ fed $)=[$ cane yield $($ tons $/$ fed $) \times$ sugar recovery \% $]$. Statistical analysis:

- Correlations coefficients were calculated between each pairs of studied traits across both planting methods and seasons according to Walker (1960).

- Multiple regression analysis was carried out for cane yield/fed or sugar yield/fed as a dependent trait across all other independent traits through bud chips and conventional planting methods in 2017/2018, 2018/2019 and over both planting methods and seasons.

\section{Results and Discussion}

\section{I- Correlation coefficients:}

Correlation coefficients between each pair of thestudied traits were calculated in each of the bud chips (Table 2), conventional planting (Table 3) methods and over both of them (Table 4) in 2017/2018 (above) and 2018/2019 (below diagonal) sowing seasons.

Unique and high positive estimates of correlation coefficients were recorded between seeding survival \% and each of brix, sucrose, purity, sugar recovery, pol and sugar yield/fed across bud chips method of values ranged from 0.581 to 0.964 in 2018/2019 (Table 2) and millable cane length, millable cane weight and sugar yield/ fed of values varied from 0.537 to 0.939 in 2017/2018 (Table 2). Otherwise, the previous results were not found for conventional planting method, reflecting the remarkable 
effect of bud chips methods on correlation coefficients corresponding to the seeding survival produced using that method. Moreover, the seeding survival\% correlated in high positive values with millable cane diameter $(0.548-0.863)$ and cane yield/ fed $(0.729 \& 0.911)$ across both planting methods (Tables 2-4). Also, the seeding survival \% associated in high positive values with tiller number/ $\mathrm{m}^{2}(0.654-0.914)$ and positive $(0.581 \& 0.387)$ with the number millable cane/ fed across conventional planting methods and over the both methods (Tables $3 \& 4$ ).

Tiller number/ $\mathrm{m}^{2}$ was correlated with the number of millable cane/ fed in high values (0.613 - 0.932) across all planting methods, except conventional planting methods in both seasons, millable cane diameter $(0.5336-0.541)$ of all planting methods in 2018/2019 season and cane yield/ fed. (0.585) across conventional methods in 2018/2019 only (Tables 2-4).

Stalk length (Early) accounted very high positive values with millable cane length (0.909-0.995), miallble cane weight $(0.408$ 0.972) for all planting methods in the two sowing seasons, and high positive correlation with cane yield/fed (0.566) and sugar yield/ fed (0.618) for only bud chips method in 2018/2019 season (Tables 2-4), reflecting the efficiency of bud chips method to change the correlation response between stalk length in early with both of cane and sugar yields/ fed.

Positive correlation estimates (0.282-0.949) were obtained between number millable cane/ fed and each of sucrose $\%$, purity $\%$, sugar recovery, pol\% and sugar yield/fed with conventional planting method in both seasons (Table 3) and purity\% (0.737) and sugar recovery (0.561) over both planting methods in 2017/2018 season (Table 4).

Strong association (0.633-0.926) found between both of millable cane length and weight over all planting methods and seasons. Also, millable cane length positively correlated with each of cane yield/ fed (0.698) in 2017/2018 and purity \% (0.502) and sugar yield/ fed (0.616) in 2018/2019 (Tables 2-4). 
Strong and positive correlation coefficients recorded between millable cane diameter and cane yield/ fed for both planting methods in the two sowing seasons which possessed values of 0.717-0.995, except for bud chips methods in 2017/2018 was 0.273 . Also, millable cane diameter associated with millable cane weight in mid positive values (0.458-0.583) for both planting methods in sowing season of 2018/2019 (Tables 2- 4). 
Eqyptian Sugar Dournal, (2021) Ool.16 1-25

11

Table 2: Correlation coefficients between each pairs of studied traits for bud chips method in 2017/2018 (above diagonal) and in 2018/2019 (below

diagonal).

\begin{tabular}{|c|c|c|c|c|c|c|c|c|c|c|c|c|c|c|}
\hline & $\begin{array}{c}\text { Seeding } \\
\text { survival } \\
\%\end{array}$ & $\begin{array}{c}\text { Tiller } \\
\text { number } \\
\mathrm{m}^{2}\end{array}$ & $\begin{array}{c}\text { Stalk } \\
\text { length } \\
\text { (Early) }\end{array}$ & $\begin{array}{l}\text { Number } \\
\text { millable } \\
\text { cane/Fed. }\end{array}$ & $\begin{array}{c}\text { Millable } \\
\text { cane } \\
\text { length }\end{array}$ & $\begin{array}{l}\text { Millable } \\
\text { cane } \\
\text { diameter }\end{array}$ & $\begin{array}{c}\text { Millable } \\
\text { cane } \\
\text { weight }\end{array}$ & Brix & $\begin{array}{l}\text { Sucrose } \\
\%\end{array}$ & $\begin{array}{c}\text { Purity } \\
\%\end{array}$ & $\begin{array}{c}\text { Sugar } \\
\text { recovery }\end{array}$ & $\begin{array}{l}\text { Pol } \\
\%\end{array}$ & $\begin{array}{l}\text { Cane } \\
\text { yield } \\
\text { /fed. }\end{array}$ & $\begin{array}{l}\text { Sugar } \\
\text { yield } \\
\text { /fed. }\end{array}$ \\
\hline Seeding survival $\%$ & - & -0.158 & 0.395 & -0.384 & 0.705 & 0.548 & 0.939 & 0.226 & -0.556 & -0.695 & -0.605 & $\overline{0.393}$ & 0.911 & 0.537 \\
\hline Tiller number $/ \mathrm{m}^{2}$ & -0.878 & - & -0.547 & 0.932 & -0.384 & 0.574 & -0.464 & $\overline{0.746}$ & -0.460 & -0.344 & -0.425 & $\overline{-} \overline{542}$ & -0.542 & -0.774 \\
\hline Stalk length (Early) & 0.350 & -0.151 & - & -0.372 & 0.921 & -0.502 & 0.696 & $\begin{array}{c}- \\
0.069\end{array}$ & -0.428 & -0.477 & -0.443 & $\overline{-}$ & 0.491 & 0.186 \\
\hline $\begin{array}{l}\text { Number millable } \\
\text { cane/Fed. }\end{array}$ & -0.970 & 0.777 & -0.232 & - & -0.336 & 0.242 & -0.607 & $\begin{array}{c}- \\
0.900\end{array}$ & -0.444 & -0.290 & -0.396 & $\begin{array}{c}- \\
0.576\end{array}$ & -0.729 & -0.951 \\
\hline Millable cane length & 0.393 & -0.257 & 0.988 & -0.243 & - & -0.126 & 0.835 & $\begin{array}{c}- \\
0.072\end{array}$ & -0.643 & -0.724 & -0.671 & $\overline{-}-\overline{557}$ & 0.698 & 0.261 \\
\hline $\begin{array}{l}\text { Millable cane } \\
\text { diameter }\end{array}$ & -0.070 & 0.538 & 0.241 & -0.100 & 0.090 & - & 0.235 & $\begin{array}{c}- \\
0.027\end{array}$ & -0.365 & -0.412 & -0.385 & $\begin{array}{c}- \\
0.280\end{array}$ & 0.273 & 0.066 \\
\hline Millable cane weight & 0.345 & -0.044 & 0.972 & -0.277 & 0.926 & 0.458 & - & 0.356 & -0.426 & -0.578 & -0.477 & $\begin{array}{c}- \\
0.263\end{array}$ & 0.973 & 0.665 \\
\hline Brix & 0.581 & -0.900 & -0.084 & -0.441 & 0.059 & -0.849 & -0.257 & - & 0.680 & 0.536 & 0.635 & $\begin{array}{c}0.802 \\
0\end{array}$ & 0.552 & 0.935 \\
\hline Sucrose $\%$ & 0.947 & -0.965 & 0.380 & -0.846 & 0.464 & -0.356 & 0.297 & 0.774 & - & 0.984 & 0.998 & 0.983 & -0.230 & 0.382 \\
\hline Purity \% & 0.964 & -0.941 & 0.429 & -0.872 & 0.502 & -0.278 & 0.361 & 0.717 & 0.996 & - & 0.993 & 0.934 & -0.401 & 0.210 \\
\hline Sugar recovery & 0.955 & -0.959 & 0.391 & -0.858 & 0.471 & -0.329 & 0.314 & 0.756 & 1.000 & 0.998 & - & 0.970 & -0.287 & 0.326 \\
\hline Pol \% & 0.916 & -0.988 & 0.298 & -0.808 & 0.394 & -0.454 & 0.198 & 0.841 & 0.993 & 0.980 & 0.990 & - & -0.053 & 0.541 \\
\hline Cane yield /fed. & 0.299 & 0.187 & 0.566 & -0.405 & 0.444 & 0.900 & 0.743 & $\begin{array}{c}- \\
0.594 \\
\end{array}$ & 0.048 & 0.133 & 0.077 & $\overline{-} .065$ & - & 0.811 \\
\hline Sugaryield /fed & 0.928 & -0.669 & 0.618 & -0.907 & 0.616 & 0.221 & 0.651 & 0.287 & 0.828 & 0.873 & 0.844 & 0.759 & 0.600 & - \\
\hline
\end{tabular}



Again, unique strong and positive correlations were obtained between millable cane weight and each of cane yield/ fed (0.973 and $0.743)$ and sugar yield/fed (0.663 and 0.651$)$ with only bud chip method in 2017/2018 and 2018/2019, respectively (Table 2). Moreover, millable cane weight and cane yield/fed possessed correlation coefficients of 0.883 and 0.637 over both planting methods in 2017/2018 and 2018/20019, respectively (Table 4).

Brix recorded high and positive correlation with each of sucrose $\%$, purity $\%$, sugar recovery, pol $\%$ and sugar yield/ fed across both planting methods in the two sowing seasons of values ranged from 0.444 to 0.978 , except with sugar yield/ fed (0.287) with bud chips method in the second season (Tables 2-4).

In the same trend, sucrose \% was in very high and positive correlations (0.672-1.000) with purity, sugar recovery, pol \% and sugar yield/ fed across both planting methods, except with sugar yield/ fed of bud chips in first season (0.382) as revealed in Tables 2-4.

Purity \% correlated strongly and positively with each of sugar recovery, pol \% and sugar yield/fed of values varied from 0.506 to 0.999 across both of planting methods and sowing seasons, except sugar yield/ fed (0.210) with bud chips in 2017/2018 (Tables 2-4).

The same view of results could be found between sugar recovery and each of pol \% and sugar yield/ fed which recorded correlation values of $0.633-0.994$ across both of planting methods and seasons, except 0.326 with sugar yield/ fed of bud chips method in 2017/2018 (Tables 2-4).

It is remarkable results that the correlation coefficients between each other of sucrose $\%$, purity $\%$, sugar recovery and pol $\%$ were equal or closes to unity, reflecting the very strong genetic make-up of those traits among them.

Pol \% correlated positively with sugar yield/ fed in high values (0.541-0.942) over both planting methods and seasons (Tables 2-4).

High correlation values were recorded between cane yield/ fed and sugar yield/ fed across bud chips (0.600-0.811) in both sowing seasons and over the two planting methods (0.551) in 2017/2018 season (Tables 2 and 4). 

Eqyptian Sugar Dournal, (2021) Ool.16 1-25

13

Table 3: Correlation coefficients between each pairs of studied traits for conventional method in 2017/2018 (above diagonal) and in 2018/2019 (below diagonal).

\begin{tabular}{|c|c|c|c|c|c|c|c|c|c|c|c|c|c|c|}
\hline & $\begin{array}{c}\text { Seeding } \\
\text { survival } \\
\%\end{array}$ & $\begin{array}{c}\text { Tiller } \\
\text { number } \\
\mathrm{m}^{2}\end{array}$ & $\begin{array}{c}\text { Stalk } \\
\text { length } \\
\text { (Early) }\end{array}$ & $\begin{array}{l}\text { Number } \\
\text { millable } \\
\text { cane/Fed }\end{array}$ & $\begin{array}{c}\text { Millable } \\
\text { cane } \\
\text { length }\end{array}$ & $\begin{array}{c}\text { Millable } \\
\text { cane } \\
\text { diameter }\end{array}$ & $\begin{array}{c}\text { Millable } \\
\text { cane } \\
\text { weight }\end{array}$ & Brix & $\begin{array}{c}\text { Sucrose } \\
\%\end{array}$ & $\begin{array}{c}\text { Purity } \\
\%\end{array}$ & $\begin{array}{c}\text { Sugar } \\
\text { recovery }\end{array}$ & $\begin{array}{l}\text { Pol } \\
\%\end{array}$ & $\begin{array}{l}\text { Cane } \\
\text { yield } \\
\text { /fed. }\end{array}$ & $\begin{array}{l}\begin{array}{l}\text { Sugar } \\
\text { yield } \\
\text { /fed. }\end{array} \\
\end{array}$ \\
\hline Seeding survival \% & - & 0.654 & -0.785 & 0.020 & -0.564 & 0.749 & -0.149 & -0.820 & -0.607 & -0.293 & -0.548 & -0.728 & 0.729 & 0.027 \\
\hline Tiller number $/ \mathbf{m}^{2}$ & 0.914 & - & -0.848 & 0.671 & -0.955 & 0.174 & -0.812 & -0.341 & 0.059 & 0.454 & 0.146 & -0.141 & 0.247 & 0.300 \\
\hline Stalk length (Early) & -0.954 & -0.757 & - & -0.615 & 0.909 & -0.627 & 0.408 & 0.308 & -0.014 & -0.334 & -0.084 & 0.149 & $0 . \overline{704}$ & -0.589 \\
\hline $\begin{array}{l}\text { Number millable } \\
\text { cane/Fed. }\end{array}$ & 0.581 & 0.290 & -0.669 & - & -0.826 & -0.094 & -0.680 & 0.460 & 0.767 & 0.949 & 0.818 & 0.629 & $\begin{array}{c}0.005 \\
2\end{array}$ & 0.783 \\
\hline Millable cane length & -0.927 & -0.729 & 0.989 & -0.576 & - & -0.245 & 0.734 & 0.117 & -0.273 & -0.620 & -0.352 & -0.083 & $\begin{array}{c}- \\
0.349\end{array}$ & -0.569 \\
\hline $\begin{array}{l}\text { Millable cane } \\
\text { diameter }\end{array}$ & 0.263 & 0.536 & -0.104 & -0.633 & -0.184 & - & 0.433 & -0.460 & -0.440 & -0.355 & -0.429 & -0.462 & 0.989 & 0.342 \\
\hline $\begin{array}{l}\text { Millable cane } \\
\text { weight }\end{array}$ & -0.680 & -0.428 & 0.730 & -0.988 & 0.633 & 0.521 & - & 0.027 & -0.328 & -0.638 & -0.401 & -0.159 & 0.358 & -0.086 \\
\hline Brix & 0.406 & 0.243 & -0.558 & -0.057 & -0.673 & 0.421 & 0.055 & - & 0.918 & 0.680 & 0.879 & 0.978 & $\overline{0.365}$ & 0.547 \\
\hline Sucrose \% & 0.197 & -0.207 & -0.479 & 0.545 & -0.515 & -0.490 & -0.451 & 0.583 & - & 0.915 & 0.996 & 0.980 & $\overline{0.310}$ & 0.688 \\
\hline Purity \% & 0.132 & -0.281 & -0.414 & 0.609 & -0.430 & -0.625 & -0.505 & 0.444 & 0.987 & - & 0.947 & 0.817 & $\overline{0.211}$ & 0.709 \\
\hline Sugar recovery & 0.176 & -0.232 & -0.460 & 0.570 & -0.488 & -0.538 & -0.473 & 0.537 & 0.998 & 0.994 & - & 0.959 & $\overline{0.294}$ & 0.702 \\
\hline Pol \% & 0.254 & -0.125 & -0.529 & 0.442 & -0.587 & -0.317 & -0.362 & 0.727 & 0.982 & 0.938 & 0.970 & - & $0 . \overline{347}$ & 0.630 \\
\hline Cane yield /fed. & 0.341 & 0.585 & -0.197 & -0.568 & -0.278 & 0.995 & 0.455 & 0.490 & -0.417 & -0.559 & -0.467 & -0.239 & - & 0.474 \\
\hline Sugar yield/fed & 0.405 & 0.098 & -0.634 & 0.282 & -0.718 & 0.016 & -0.242 & 0.910 & 0.863 & 0.770 & 0.834 & 0.942 & 0.098 & - \\
\hline
\end{tabular}


Table 4: Correlation coefficients between each pairs of studied traits over both bud chips and conventional methods in 2017/2018 (above diagonal) and in 2018/2019 (below diagonal).

\begin{tabular}{|c|c|c|c|c|c|c|c|c|c|c|c|c|c|c|}
\hline & $\begin{array}{c}\text { Seeding } \\
\text { survival } \\
\%\end{array}$ & $\begin{array}{c}\text { Tiller } \\
\text { number } \\
\mathrm{m}^{2}\end{array}$ & $\begin{array}{c}\text { Stalk } \\
\text { length } \\
\text { (Early) }\end{array}$ & $\begin{array}{l}\text { Number } \\
\text { millable } \\
\text { cane/Fed. }\end{array}$ & $\begin{array}{c}\text { Millable } \\
\text { cane } \\
\text { length }\end{array}$ & $\begin{array}{c}\text { Millable } \\
\text { cane } \\
\text { diameter }\end{array}$ & $\begin{array}{c}\text { Millable } \\
\text { cane } \\
\text { weight }\end{array}$ & Brix & $\begin{array}{c}\text { Sucrose } \\
\%\end{array}$ & $\begin{array}{c}\text { Purity } \\
\%\end{array}$ & $\begin{array}{c}\text { Sugar } \\
\text { recovery }\end{array}$ & $\begin{array}{c}\mathrm{Pol} \\
\%\end{array}$ & $\begin{array}{c}\text { Cane } \\
\text { Yield /fed. }\end{array}$ & $\begin{array}{l}\text { Sugar } \\
\text { yield } \\
\text { /fed. }\end{array}$ \\
\hline Seeding survival $\%$ & - & 0.739 & -0.611 & 0.177 & -0.311 & 0.863 & 0.023 & $0 . \overline{-}$ & -0.629 & -0.447 & -0.590 & $0 . \overline{715}$ & 0.306 & -0.263 \\
\hline Tiller number $/ \mathrm{m}^{2}$ & 0.722 & - & -0.775 & 0.724 & -0.736 & 0.382 & -0.656 & $\overline{-}$ & -0.237 & 0.068 & -0.162 & $\overline{0.441}$ & -0.369 & -0.435 \\
\hline Stalk length (Early) & -0.960 & -0.503 & - & -0.807 & 0.917 & -0.554 & 0.480 & 0.160 & -0.220 & -0.434 & -0.274 & $\begin{array}{c}- \\
0.058\end{array}$ & 0.017 & -0.323 \\
\hline $\begin{array}{l}\text { Number millable } \\
\text { cane/Fed. }\end{array}$ & 0.387 & 0.613 & -0.366 & - & -0.973 & -0.036 & -0.886 & 0.018 & 0.494 & 0.737 & 0.561 & 0.290 & -0.571 & 0.032 \\
\hline Millable cane length & -0.972 & -0.546 & 0.995 & -0.320 & - & -0.176 & 0.757 & $\overline{0.014}$ & -0.466 & -0.696 & -0.528 & 0.274 & 0.366 & -0.170 \\
\hline $\begin{array}{l}\text { Millable cane } \\
\text { diameter }\end{array}$ & 0.209 & 0.541 & 0.080 & -0.275 & -0.022 & - & 0.392 & $\overline{0.433}$ & -0.438 & -0.388 & -0.433 & $0 . \overline{-}$ & 0.717 & 0.207 \\
\hline Millable cane weight & -0.753 & -0.295 & 0.900 & -0.551 & 0.850 & 0.486 & - & 0.091 & -0.368 & -0.617 & -0.437 & - & 0.883 & 0.332 \\
\hline Brix & 0.232 & -0.464 & -0.410 & -0.613 & -0.410 & -0.201 & -0.319 & - & 0.887 & 0.684 & 0.835 & 0.962 & 0.079 & 0.791 \\
\hline Sucrose \% & -0.187 & -0.812 & -0.068 & -0.613 & -0.033 & -0.521 & -0.162 & 0.880 & - & 0.951 & 0.997 & 0.975 & -0.246 & 0.672 \\
\hline Purity \% & -0.243 & -0.846 & -0.018 & -0.600 & 0.021 & -0.558 & -0.138 & 0.845 & 0.998 & - & 0.973 & 0.857 & -0.425 & 0.506 \\
\hline Sugar recovery & -0.207 & -0.824 & -0.051 & -0.611 & -0.014 & -0.532 & -0.153 & 0.869 & 1.000 & 0.999 & - & 0.953 & -0.298 & 0.633 \\
\hline Pol $\%$ & -0.119 & -0.765 & -0.125 & -0.633 & -0.097 & -0.464 & -0.184 & 0.918 & 0.996 & 0.988 & 0.994 & - & -0.093 & 0.756 \\
\hline Cane yield /fed. & 0.024 & 0.334 & 0.243 & -0.469 & 0.140 & 0.973 & 0.637 & $0 . \overline{116}$ & -0.375 & -0.406 & -0.383 & 0.324 & - & 0.551 \\
\hline Sugaryield /fed & -0.208 & -0.628 & 0.126 & -0.958 & 0.093 & 0.120 & 0.290 & 0.814 & 0.775 & 0.753 & 0.770 & 0.803 & 0.295 & - \\
\hline
\end{tabular}


Finally, it is clear results that negative correlation coefficients could be found among some traits such as tiller number/ $\mathrm{m}^{2}$, stalk length (Early), length and diameter of millable cane with quality traits, reflecting the adverse correlated genetic make-up for those traits.

The cane yield was considered as the most important trait of sugarcane and positively and significantly correlated with the number of millable canes, stalk length, stalk diameter, and stalk weight (Chaudhary \& Joshi, 2005; Kumar \& Kumar, 2014), but negatively correlated with brix (Kumar \& Kumar, 2014). Weight of number of millable canes revealed positive and significant correlation with the number of millable canes (Tyagi \& Lal 2007). Moreover, all quality parameters like juice brix, sucrose $\%$ in juice and commercial cane sugar $\%$ had highly positive and significant genotypic correlation with Pol \% in cane. Also the number of millable cane, single cane weight and cane height showed significant positive correlation with ratoon yield and sugar tons/ha, but there was weak negative correlation between number of millable cane and single cane weight (Singh, et al. 2005; Brasileriro et al. 2013; Abo-Elwafa et al. 2015; Pandya \& Patal 2017; Ahmed et al. 2019; Agrowal \& Kumar 2018; Anbanandan et al. 2020).

Swamy Gowda et al., (2016) found that the cane yield was positively and significantly correlated with sugar yield, single stalk weight, number of tillers and stalk length. Also, positive significant correlation coefficients of number of millable cane and stalk diameter were recorded with cane yield. Cane yield was negatively and significantly correlated with brix and pol. Otherwise, sugar yield showed positive and significant correlation with single stalk weight, cane length, pol and purity.

\section{II- Regression analysis:}

Multiple regression analysis was carried out for cane yield/fed or sugar yield/fed as a dependent trait across all other independent traits through bud chips and conventional planting methods in 2017/2018, 2018/2019 and over both planting methods and seasons (Table 5 and 6).

-Cane yield/fed (dependent trait): 
It is clear results that three predictors (traits) among all independent traits were obtained in each case and produced $\mathrm{R}^{2}$ values equally to unity in all cases for regression analysis. This result means that the three predictors possessed the main contributions in cane yield/fed for bud chips, conventional and over both planting methods in 2017/2018, 2018/2019 and over both seasons (Table 5).

It is remarkable view that the sugar yield/fed was the main predictor across the two planting methods and sowing seasons and to be the first order contribution for cane yield/fed. The miallable cane diameter and its length were in the second and third orders of contributions for cane yield/fed, respectively. Moreover, seedling survival\% came as fourth order and both of miallable cane weight and number of miallable cane/fed together came as fifth order contribution in cane yield/fed.

It was noticed that sugar yield/fed., millable cane diameter and its length were the predictors traits for cane yield/fed in bud chips planting method. While, sugar yield/ fed, seedling survival\%, millable cane diameter and its weight revealed to be the predictor contributions for cane yield/fed. in conventional planting method. The previous predicted traits in addition to the number of millable cane yield/fed were the predictors contributed to the cane yield/fed over both planting methods and seasons.

Consequently, these predictors traits, i.e., sugar yield/fed, millable cane diameter, millable cane length, seedling survival\%, millable cane weight and number of millable cane/fed could be used as powerful selection criteria for high cane yield/fed.

Finally, it is clear results that negative correlation coefficients could be found among some traits such as tiller number/ $\mathrm{m}^{2}$, stalk length (Early), length and diameter of millable cane with quality traits, reflecting the adverse correlated genetic make-up for those traits.

The cane yield was considered as the most important trait of sugarcane and positively and significantly correlated with the number of millable canes, stalk length, stalk diameter, and stalk weight (Chaudhary \& Joshi, 2005; Kumar \& Kumar, 2014), but negatively correlated with brix (Kumar \& Kumar, 2014). Weight 
of number of millable canes revealed positive and significant correlation with the number of millable canes (Tyagi \& Lal 2007). Moreover, all quality parameters like juice brix, sucrose $\%$ in juice and commercial cane sugar $\%$ had highly positive and significant genotypic correlation with Pol \% in cane. Also the number of millable cane, single cane weight and cane height showed significant positive correlation with ratoon yield and sugar tons/ha, but there was weak negative correlation between number of millable cane and single cane weight (Singh, et al. 2005; Brasileriro et al. 2013; Abo-Elwafa et al. 2015; Pandya \& Patal 2017; Ahmed et al. 2019; Agrowal \& Kumar 2018; Anbanandan et al. 2020).

Swamy Gowda et al., (2016) found that the cane yield was positively and significantly correlated with sugar yield, single stalk weight, number of tillers and stalk length. Also, positive significant correlation coefficients of number of millable cane and stalk diameter were recorded with cane yield. Cane yield was negatively and significantly correlated with brix and pol. Otherwise, sugar yield showed positive and significant correlation with single stalk weight, cane length, pol and purity.

\section{II- Regression analysis:}

Multiple regression analysis was carried out for cane yield/fed or sugar yield/fed as a dependent trait across all other independent traits through bud chips and conventional planting methods in 2017/2018, 2018/2019 and over both planting methods and seasons (Table 5 and 6).

\section{-Cane yield/fed (dependent trait):}

It is clear results that three predictors (traits) among all independent traits were obtained in each case and produced $\mathrm{R}^{2}$ values equally to unity in all cases for regression analysis. This result means that the three predictors possessed the main contributions in cane yield/fed for bud chips, conventional and over both planting methods in 2017/2018, 2018/2019 and over both seasons (Table 5).

It is remarkable view that the sugar yield/fed was the main predictor across the two planting methods and sowing seasons and 
to be the first order contribution for cane yield/fed. The miallable cane diameter and its length were in the second and third orders of contributions for cane yield/fed, respectively. Moreover, seedling survival\% came as fourth order and both of miallable cane weight and number of miallable cane/fed together came as fifth order contribution in cane yield/fed.

It was noticed that sugar yield/fed., millable cane diameter and its length were the predictors traits for cane yield/fed in bud chips planting method. While, sugar yield/ fed, seedling survival\%, millable cane diameter and its weight revealed to be the predictor contributions for cane yield/fed. in conventional planting method. The previous predicted traits in addition to the number of millable cane yield/fed were the predictors contributed to the cane yield/fed over both planting methods and seasons.

Consequently, these predictors traits, i.e., sugar yield/fed, millable cane diameter, millable cane length, seedling survival\%, millable cane weight and number of millable cane/fed could be used as powerful selection criteria for high cane yield/fed. 
Table 5: Multiple regression analysis for cane yield/fed as dependent trait against all independent studied traits using bud chips and conventional planting methods in 2017/2018, 2018/2019 and over both seasons.

\begin{tabular}{|c|c|c|c|c|c|}
\hline $\begin{array}{l}\text { Dependent } \\
\text { trait }\end{array}$ & $\begin{array}{l}\text { Planting } \\
\text { method }\end{array}$ & Season & Predictors & $\mathbf{R}^{2}$ & Predicted regression equation \\
\hline \multirow{6}{*}{$\begin{array}{c}\text { Cane yield/fed } \\
\text { (CaYF) }\end{array}$} & & $2017 / 2018$ & $\begin{array}{c}\text { Millable cane length (MCL), } \\
\text { Millable cane diameter } \\
\text { (MCD), Sugar yield/fed } \\
\text { (SuYF) }\end{array}$ & 1.00 & $\mathrm{CaYF}=-12.967+0.081 \mathrm{MCL}+3.732 \mathrm{MCD}+5.178 \mathrm{SuYF}$ \\
\hline & & 2018/2019 & $\begin{array}{c}\text { Millable cane length (MCL), } \\
\text { Millable cane diameter } \\
\text { (MCD), Sugar yield/fed } \\
\text { (SuYF) }\end{array}$ & 1.00 & $\mathrm{CaYF}=11.963+0.032 \mathrm{MCL}+8.077 \mathrm{MCD}+1.422 \mathrm{SuYF}$ \\
\hline & \multirow{2}{*}{$\begin{array}{l}\text { Conventional } \\
\text { planting } \\
\text { method }\end{array}$} & $2017 / 2018$ & $\begin{array}{l}\text { Seedling survival\% (SSP), } \\
\text { Millable cane weight (MCW), } \\
\text { Sugar yield/fed (SuYF) }\end{array}$ & 1.00 & $\mathrm{CaYF}=1.053+0.336 \mathrm{SSP}+9.001 \mathrm{MCW}+3.048 \mathrm{SuYF}$ \\
\hline & & $2018 / 2019$ & $\begin{array}{c}\text { Seedling survival\% (SSP), } \\
\text { Millable cane diameter } \\
\text { (MCD), Sugar yield/fed } \\
\text { (SuYF) }\end{array}$ & 1.00 & $\mathrm{CaYF}=23.771+0.016 \mathrm{SSP}+8.236 \mathrm{MCD}+0.322 \mathrm{SuYF}$ \\
\hline & \multirow{2}{*}{$\begin{array}{l}\text { Bud chips \& } \\
\text { conventional } \\
\text { planting } \\
\text { methods }\end{array}$} & $2017 / 2018$ & $\begin{array}{c}\text { Number of millable cane/fed } \\
\text { (NMCF), Millable cane } \\
\text { diameter (MCD), Sugar } \\
\text { yield/fed (SuYF) }\end{array}$ & 1.00 & $\mathrm{CaYF}=60.144-0.738 \mathrm{NMCF}+4.691 \mathrm{MCD}+2.919 \mathrm{SuYF}$ \\
\hline & & 2018/2019 & $\begin{array}{c}\text { Millable cane length (MCL), } \\
\text { Millable cane diameter } \\
\text { (MCD), Sugar yield/fed } \\
\text { (SuYF) }\end{array}$ & 1.00 & $\mathrm{CaYF}=13.695+0.029 \mathrm{MCL}+8.404 \mathrm{MCD}+0.984 \mathrm{SuYF}$ \\
\hline
\end{tabular}


Table 6: Multiple regression analysis for sugar yield/fed as dependent trait against all independent studied traits using bud chips and conventional planting methods in 2017/2018 and 2018/2019 seasons.

\begin{tabular}{|c|c|c|c|c|c|}
\hline $\begin{array}{l}\text { Dependent } \\
\text { trait }\end{array}$ & $\begin{array}{l}\text { Planting } \\
\text { method }\end{array}$ & Season & Predictors & $\mathbf{R}^{2}$ & Predicted regression equation \\
\hline \multirow{6}{*}{$\begin{array}{c}\text { Sugar } \\
\text { yield/fed } \\
(\text { SuYF })\end{array}$} & \multirow{2}{*}{$\begin{array}{l}\text { Bud chips } \\
\text { planting } \\
\text { method }\end{array}$} & $2017 / 2018$ & $\begin{array}{l}\text { Millable cane diameter } \\
\text { (MCD), Pol\% (PolP), } \\
\text { Cane yield/fed (CaYF) }\end{array}$ & 1.00 & $\begin{array}{c}\text { SuYF }=-18.509+0.0001 \text { MCD+1.384 PolP } \\
+0.105 \text { CaYF }\end{array}$ \\
\hline & & 2018/2019 & $\begin{array}{c}\text { Millable cane lenght } \\
\text { (MCL), Sucrose\% } \\
\text { (SucP), Cane yield/fed } \\
\text { (CaYF) }\end{array}$ & 1.00 & $\begin{aligned} \text { SuYF }= & -9.043+0.0001 \text { MCL+0.515 } \\
& \text { SucP+0.122 CaYF }\end{aligned}$ \\
\hline & \multirow[t]{2}{*}{$\begin{array}{l}\text { Conventional } \\
\text { planting } \\
\text { method }\end{array}$} & $2017 / 2018$ & $\begin{array}{c}\text { Number of millable } \\
\text { cane/fed (NMCF), } \\
\text { Brix\% (Brix), Cane } \\
\text { yield/fed (CaYF) }\end{array}$ & 1.00 & $\begin{array}{c}\text { SuYF }=-\mathbf{- 1 0 . 8 3 1 + 0 . 0 6 1} \text { NMCF }+0.419 \\
\text { Brix+0.106 CaYF }\end{array}$ \\
\hline & & $2018 / 2019$ & $\begin{array}{c}\text { Stalk length elongation } \\
\text { (SLE), (PolP), Cane } \\
\text { yield/fed (CaYF) }\end{array}$ & 1.00 & $\begin{aligned} \text { SuYF }= & -13.953+0.0001 \text { SLE }+1.219 \\
& \text { PolP+0.060 CaYF }\end{aligned}$ \\
\hline & \multirow{2}{*}{$\begin{array}{l}\text { Bud chips \& } \\
\text { conventional } \\
\text { planting } \\
\text { methods }\end{array}$} & $2017 / 2018$ & $\begin{array}{c}\text { Stalk length elongation } \\
\text { (SLE), Pol\% (PolP), } \\
\text { Cane yield/fed (CaYF) }\end{array}$ & 1.00 & $\begin{array}{c}\text { SuYF }=-9.801-0.005 \text { SLE+0.886 PolP }+0.096 \\
\text { CaYF }\end{array}$ \\
\hline & & $2018 / 2019$ & $\begin{array}{c}\text { Seedling survival\% } \\
\text { (SSP), Brix\% (Brix), } \\
\text { Cane yield/fed (CaYF) }\end{array}$ & 1.00 & $\begin{array}{c}\text { SuYF }=-58.480-0.046 \text { SSP }+3.182 \text { Brix }+0.071 \\
\text { CaYF }\end{array}$ \\
\hline
\end{tabular}




\section{References}

Abo-Elwafa A, A. Hamada, H. Nosaer and H. Faheim. 2015. Assessment of somaclonal variation, correlation and stepwise regression to evaluate new sugarcane somaclones. Egyptian Sugar J. 8: 131-150.

Abo-Elwafa A. 2011. In field assessment of somaclonal variation among sugarcane clones derived through immature leaf callus culture. Egyptian Sugar J. 4: 1-19.

Agrawal R.K. and B. Kumar. 2018. Characters association and their dissection through path analysis for cane yield and its component traits in sugarcane genotypes under water logging condition. Inter. J. of Chemical Studies 6 (4): 2237-2244.

Ahmed K.I, S. B. Patil, N. B. Moger, N.G. Hanumaratti and B.T. Nadgouda. 2019. Correlation and path analysis in sugarcane hybrid clones of proven cross. J. of Pharmacognosy and Phytochemistry, 8(2): 781-783.

Ahmed, A.Z.; K.S. El-Sogheir and S.M.S. Shalaby. 2007. Performance of some sugar cane verities at different planting dates. $8^{\text {th }}$ African Crop Sci Soc Conf, El-Minia, Egypt, 27-31 Oct: 161-172.

Anbanandan V., P. Karthikeyan, R. Narayanan, S. Ranjithrajaram and J. Pranay Reddy. 2020. Path coefficient analysis in sugarcane genotypes. Plant Archives 20 (1): 1847-1848. ISSN:2581-6063 (online).

Association of Official Agricultural Chemists. 1995. Official methods of analysis published by the A.O.A.C., Box 540, Washington. USA.

Brasileiro B.P., L.A. Peternelli1 and M.H.P. Barbosa. 2013. Consistency of the results of path analysis among sugarcane experiments. Crop Breeding and Applied Biotechnology 13: 113-119.

Chaudhary R.R. and B. K. Joshi. 2005. Correlation and path coefficient analyses in sugarcane. Nepal Agric. Res. J. 6 (24):24-27. 
Devendra K, and K. Sanjay. 2014. Correlation and path coefficient analysis in sugarcane germplasm under subtropics. Progressive Agriculture, 14 (2): 312-317.

De Sousa-Vieira O. and S.B. Milligan. 2005. Interrelationships of cane yield components and their utility in sugarcane family selection: Path coefficient analysis. Interciencia, 30 (2): 1-6.

El-Taib A.B.A. 2009. Correlation and path coefficient analysis for cane sugar yield and their component traits in sugarcane. Egypt. J. Plant Breed. 13: 109-122.

Galal, M.O.A. 2015. A new technique for planting sugarcane in Egypt. Institute. Integration. Egyptian Sugar J. 8: 83-93.

Galal, M.O.A., A.M. Abou-Salama, E.A. Teama and A.Z. Ahmed. (2015). Yield response of late planted spring sugarcane to direct set sowing and transplanting. Sci. J. King Faisal Univ. (Basic Appl. Sci.), 16(1) 75-94.

Hossain, A.H.M.D. 1989. Comparative performance of different planting/transplanting techniques of sugarcane under farmers' condition [Bangladesh]. Proceedings of the 14th Annual Bangladesh Science Conference, Bangladesh Association for the Advancement of Science, Dhaka (Bangladesh). Dhaka (Bangladesh): BAAS, p. 48-49.

Kadian S.P., R. Pal and Y.S. Lather. 2006. Correlation and path coefficient analysis in sugarcane. Indian Journal of Agricultural Research, 40: 135 - 138.

Kumar S. and D. Kumar. 2014. Correlation and path coefficient analysis in sugarcane germplasm under subtropics. African J. of Agric. Res., 9 (1): 148-153.

Nosheen N.E. and M. Ashraf. 2003. Statistical Analysis of Certain Traits that Influence Sugar Recovery of Selected Sugarcane Varieties. Pakistan J. of Bio. Sci. 6 (2): 99-104.

Pandya and Patel. 2017. Studies on correlation and path analysis for quality attributes in sugarcane (Saccharum Spp. Hybrid). Int. J. Pure App. Biosci. 5 (6): 1381-1388.

Panhwar R.N, H. K. Keerio, M. A. Khan, M. A. Rajpute, G. S. Unar, M. I. Mastoi, M. Chohan, A. F. Soomro and A. R. Keerio. 2003. Relationship between Yield and Yield 
Contributing Traits in Sugarcane (Saccharum officinarum L.) Journal of Applied Sciences, 3 (2): 97-99.

Radha J.; S. Solomon; A.K. Shrivastava and A. Chandra. 2010. Sugarcane bud chips: A promising seed material. Sugar Tech, 12, Issue 1, pp 67-69.

Singh R.K, S.P. Singh and S.B. Singh. 2005. Correlation and path analysis in sugarcane ratoon. Sugar Tech., vol. 7 (4): 176178.

Sundara, B. (1995). Economics of using sugarcane mericlones for commercial planting. Coop. Sugar. 26 (6) 459-461.

Swamy Gowda S. N., K. Saravanan and C.R. Ravishankar. 2016. Correlation and path analysis for yield and quality attributes in sugarcane. International J. of Sci. Technology \& Engineering, 3 (2), ISSN (online): 2349-784X.

Tena E, F. Mekbib and A. Ayana. 2016. Correlation and Path Coefficient Analyses in Sugarcane Genotypes of Ethiopia. American Journal of Plant Sciences, 7: 1490-1497.

Thippeswamy S., S.T. kajjidoni, P.M. Salimath and J.V. Goud. 2003. Correlation and path analysis for cane yield, juice quality and their component traits in sugarcane. Sugar Tech. 5(1\&2): 65-72.

Tyagi A.P. and P. Lal. 2007. Correlation and path coefficient analysis in sugarcane. The South Pacific J. of Natural Sci. 1: 110.

Walker T.T. 1960. The use of a selection index technique in the analysis of progeny row data. Emp. Cott. Gr. Rev., 37: 81-107.

Yadav, R.L. and R.K. Sharma 1980 . Effect of nitrogen level and harvesting date on quality characteristics and yield of four sugar cane genotypes. Indian J. Agric. Sci., 50: 581-589. 


\section{الإذص العربي}

الارتباط وتهليل الانهدار لهصولي القصب والسكر ومكمناتهمها عبر زراعة قصب السكر بطريقتي شعرائح البراعم و العادية

عاطف ابوالوفا'، همهد عويس جلال2، حسن همهد نصير3، عبدالآه نوبي الصغير

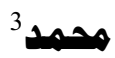

$$
\text { قسم المهاصيل - كاصية الزراعة - هامعة أسيوط }
$$

معهد بهوثث المهاصيل السكرية - مركز البهوث الزراعية - الجيزةة

شركة السكر والصنا عات التكاملية المصرية

أجرى هذا البحث في مزرعة خاصة في منطقة الشغب بجنوب إسنا

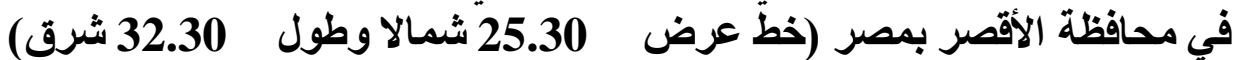

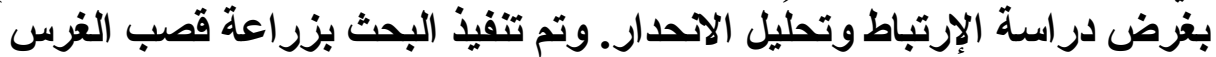

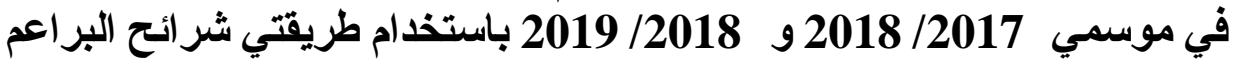
والعادية من أربعة أصناف قصب سكر هي G.T.54-9 و G.84-47 و

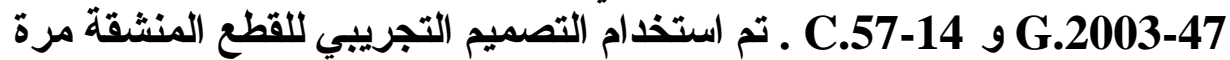

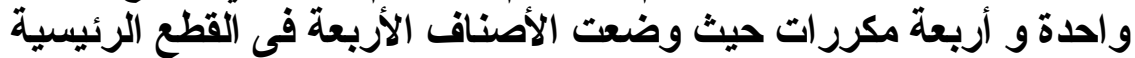

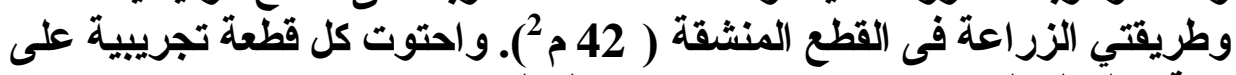
ستة خطوط بطول 7 متر و 1 متر بين الخطوط.

أوضحت أهم النتائج وجود تقدير ات عالية موجبة وفريدة بين نسبة

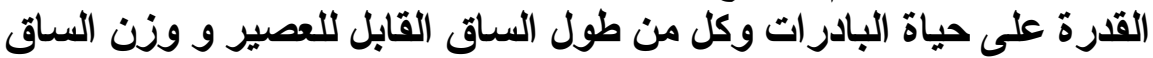
القابل للعصير و البركس و السكروز والنقاوة ولادي والسكر النظري ونسبة الحلاوة

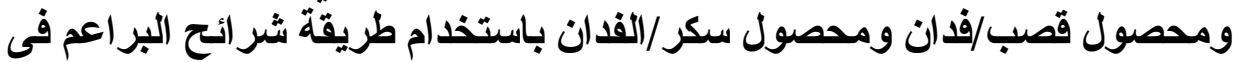

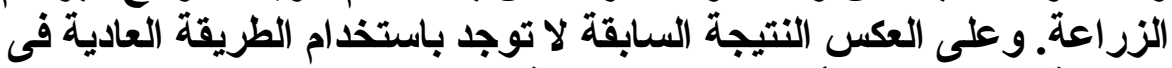

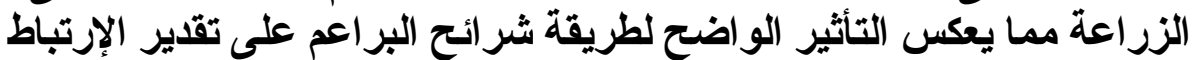

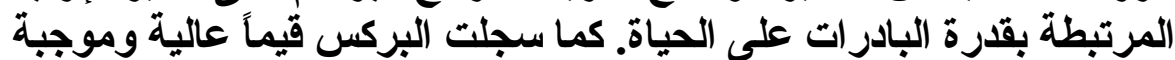

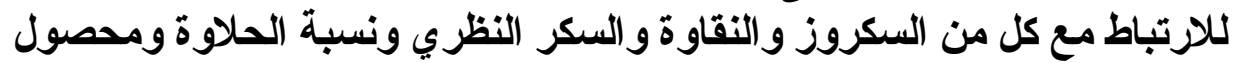

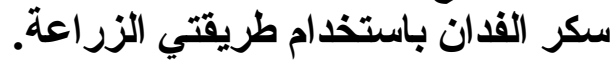


وسجلت قيماً واضحة لمعامل الإرتباط بين كل من السكروز و النقاوة

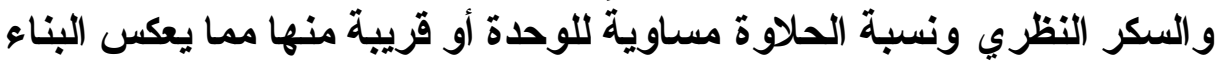
الور اثي القوى بين هذه الصفات.

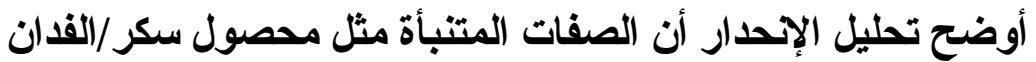

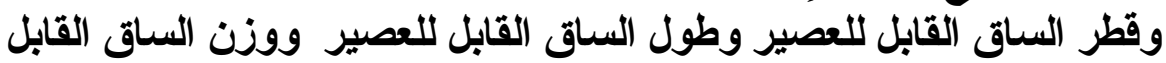

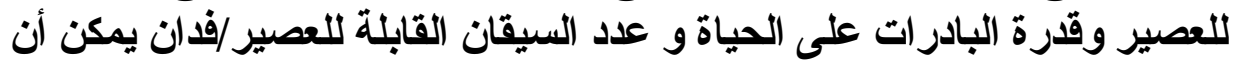

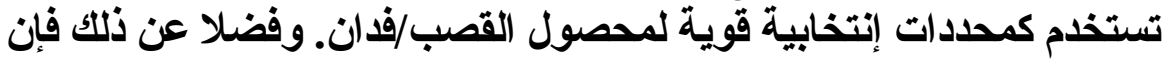

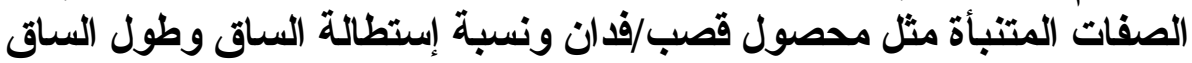

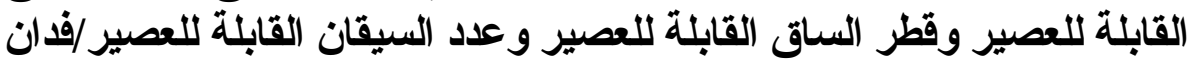

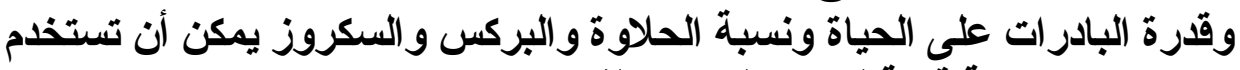

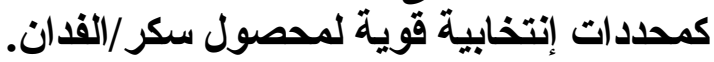

الكسمات الدالة: هعاهل الارتباط - تهليل الانهد/ر - شتل قصب السكر ثسرائح البراعم

\section{tores}

